\title{
The Challenges and Adaptation in Career for the Dwarfs: A Literature Review
}

Zaida Nor Zainudin, Nur Syuhada Abdul Rasid, Yusni Mohamad Yusop, Wan Norhayati Wan Othman, Lee Wei Rong

To Link this Article: http://dx.doi.org/10.6007/IJARBSS/v11-i2/8491

DOI:10.6007/IJARBSS/v11-i2/8491

Received: 10 January 2021, Revised: 01 February 2021, Accepted: 18 February 2021

Published Online: 28 February 2021

In-Text Citation: (Zainudin et al., 2021)

To Cite this Article: Zainudin, Z. N., Rasid, N. S. A., Yusop, Y. M., Othman, W. N. W., \& Rong, L. W. (2021). The Challenges and Adaptation in Career for the Dwarfs: A Literature Review. International Journal of Academic Research in Business and Social Sciences, 11(2), 757-770.

\section{Copyright: (c) 2021 The Author(s)}

Published by Human Resource Management Academic Research Society (www.hrmars.com)

This article is published under the Creative Commons Attribution (CC BY 4.0) license. Anyone may reproduce, distribute, translate and create derivative works of this article (for both commercial and non-commercial purposes), subject to full attribution to the original publication and authors. The full terms of this license may be seen at: http://creativecommons.org/licences/by/4.0/legalcode

Vol. 11, No. 2, 2021, Pg. 757 - 770

Full Terms \& Conditions of access and use can be found at http://hrmars.com/index.php/pages/detail/publication-ethics 


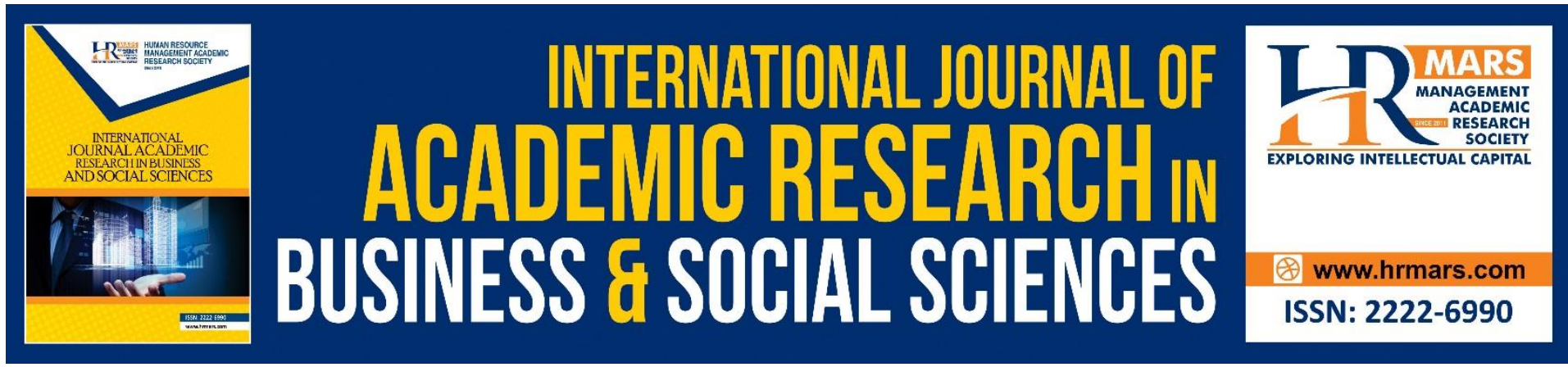

\title{
The Challenges and Adaptation in Career for the Dwarfs: A Literature Review
}

\author{
Zaida Nor Zainudin, PhD, Nur Syuhada Abdul Rasid, Yusni \\ Mohamad Yusop, PhD, Wan Norhayati Wan Othman, PhD, Lee \\ Wei Rong
}

Faculty of Educational Studies, University Putra Malaysia, Serdang Selangor. Malaysia

Email: zaidanor@upm.edu.my, nursyuhadarasid@yahoo.com, yusni_my@upm.edu.my,wannorhayati@upm.edu.my,weiweilee92@gmail.com

\begin{abstract}
The dwarfs are the disabled group that is less discussed in Malaysia. Same with other disabilities, the dwarfs had facing their own challenges. Challenges such as their physical condition, the environment, and society. The research that done in this area is very limited. Therefore, this systematic literature review objectives are to identify the challenges faced by the dwarfs and to see how the dwarfs adapt with the environment especially in career. Keywords of dwarfs and job applied in searching of articles. The inclusion and exclusion criterion were limited to year 2013 to 2018. Specific subject area was selected in screening process. A total of 12 articles were identified and used to explain the objectives of this study. The results show that the dwarfs have issues in social, environmental adjustments and medicine bound. These issues influence their career achievement and career advancement. The implication based on the help of government, self-identified and career stability on dwarfs were discussed in this study.
\end{abstract}

Keywords: Dwarfs, Jobs, Challenges

\section{Introduction}

Studies on dwarfism are still less available than those with other disabilities such as deafness, blindness, and mental disorders. The rare or lack of attention on dwarfism is due to the condition is rare to compare to other disorder or disabilities. The most common form of dwarf is Achondroplasia where it only happened 1 in 25000 people in the world (Heider et al., 2013). As a result, the lack of information for these dwarves, cause misunderstood by society. Through this study, hopefully, the information obtained can educate and provided knowledges about dwarves who are often misinterpreted as disabled to the public (Baidi et al., 2018).

Dwarfism or dwarf refers to the extraordinary shortage in normal human height or growth defect (Di George \& Paschkis, 1957). According to Kruse (2002), these group of people is called as little people, later, they described little people by using various words: short stature, microsomia, midget, dwarfism, freak, or dwarf. The dwarf is those individuals their height is not exceeding $120 \mathrm{~cm}$ in the early year (Di George \& Paschkis, 1957). Later, there is more 
criterion for determine an individual as a dwarf is define in. Research had found out that, various factor is causing an individual becoming dwarf. Those factors are genetic, nutritional, and hormonal. There are various hormone factors and genetic disorders that can cause the dwarf to reach an altitude of just 1.42 meters in adulthood (Kruse, 2002).

According to Guse \& Harvey (2010), there are more than 200 types of dwarves listed. However, almost $80 \%$ is related with Achondroplasia. Achondroplasia is a rare autosomal dominant genetic disease. Individual with Achondroplasia usually has short limbs, large heads with prominent foreheads, lordosis (back spine), and trident hand (short and fluffy fingers such as twigs) (Dumitra et al., 2013). Achondroplasia also link with various health issues such as respiratory, motor impairment, apnea, spinal stenosis, and spinal cord compassion. Dwarfs who's with the disease of Achondroplasia need to be monitored by medical teams especially during their early age since they are born (Dumitra et al., 2013). However, the dwarf's mental intelligence is as normal as a normal human being (Dumitra et al., 2013). Dwarves score the same as normal individual in the intelligent test (Baidi et al., 2018).

Most countries did not define dwarves as disabled nowadays, but rather as differences in body size. This is because only physical differences can be seen compared to average height individual. Some of the dwarfs are physically perfect just like other normal human beings in smaller sizes (Kruse, 2002). Because of this difference, the dwarves are easily seen in the community. As a result, most of these dwarves are stressed out by the public's attention. Also, some dwarves exclude themselves from society because of a lack of confidence in the public. Besides, their self-image and negative perception of the public see them as disabled make them lack social interaction with society (Kim et al., 2015). It has disrupted the psychology and emotional aspects that may affect the quality of life of the dwarf group. Dwarves are deserving better quality life in socializing, family, and work interruption (Kim et al., 2015).

\section{Objectives}

The objectives of this study are to explore the challenges and adaptations of the dwarves in the world of work. Because researches and articles related to the dwarves are very limited in the context of Malaysia, the articles for information search are not only limited to Malaysia articles. The content can be used as additional information. The following questions as a guide to this study are:

2.1 What are the statistics of the dwarf in Malaysia?

- Describe the categories of dwarf and the number of the dwarf in Malaysia.

2.2 What are the challenges faced by dwarfs?

- Identify the challenges faced by dwarfs in everyday life, especially in the career environment through previous research articles.

2.3 How do dwarfism groups adapt to the environment especially in the work world?

- List the methods and techniques of dwarfism patients facing challenges and adapt them to daily life especially in the career.

\section{Methodology}

The systematic literature review was first initial using the keyword "dwarfism". The keywords are used to smaller the number of articles search. This is followed by the specific process of finding the appropriate journal in line with the objective. Search and journal articles in the Malay language in Malaysia and the context of extremely limited. The journals are also very much in the medical field compared to the social sciences. As a result, searches are not limited by location and year as long as journals and articles have the desired information in line with 
the objective. Highlights of the literature are scholarly articles that contain current information including research findings, theories, and methods of conducting a topic.

\section{Search Approach}

Journal articles were selected primarily from the SCOPUS database. The searching process started by using the keyword of Dwarfism and job. The use of keywords was able to find a total of 380 articles in the first searching process. The low number of articles found showed that the lack of research conduct on this topic.

Next, the year was limited from 2013 to 2018. It helps to get recent journal articles publication. The articles' numbers were limited to 220 articles. Then, the identified articles were also screened according to the subject area. Academic search complete, psychology, and behavior sciences collection were selected in the subject area. The articles were limited to 46 articles. This method is known as the inclusion and exclusion criteria method. A better description showed in Table 1.

Finally, the remaining articles left were all reviewed according to their titles and abstract, only those were relatable to the content of this study will be selected. A total of 12 articles were selected and included in this review study. The flow of the systematic review process showed in Figure 1.

Table 1. Inclusion and Exclusion Criteria

\begin{tabular}{|c|c|c|c|}
\hline Criteria & Eligibility & Articles Obtained & $\begin{array}{l}\text { Articles } \\
\text { remain }\end{array}$ \\
\hline Keywords & Dwarfism and Job & 380 & 380 \\
\hline Years & 2013 to 2018 & 220 & 220 \\
\hline Subject & $\begin{array}{l}\text { Academic Search Complete } \\
\text { Psychology } \\
\text { Behavioral and } \\
\text { Collection }\end{array}$ & 46 & 46 \\
\hline $\begin{array}{l}\text { Title article and } \\
\text { Journal }\end{array}$ & $\begin{array}{l}\text { Dwarfism } \\
\text { Little People } \\
\text { Job }\end{array}$ & 12 & 12 \\
\hline
\end{tabular}




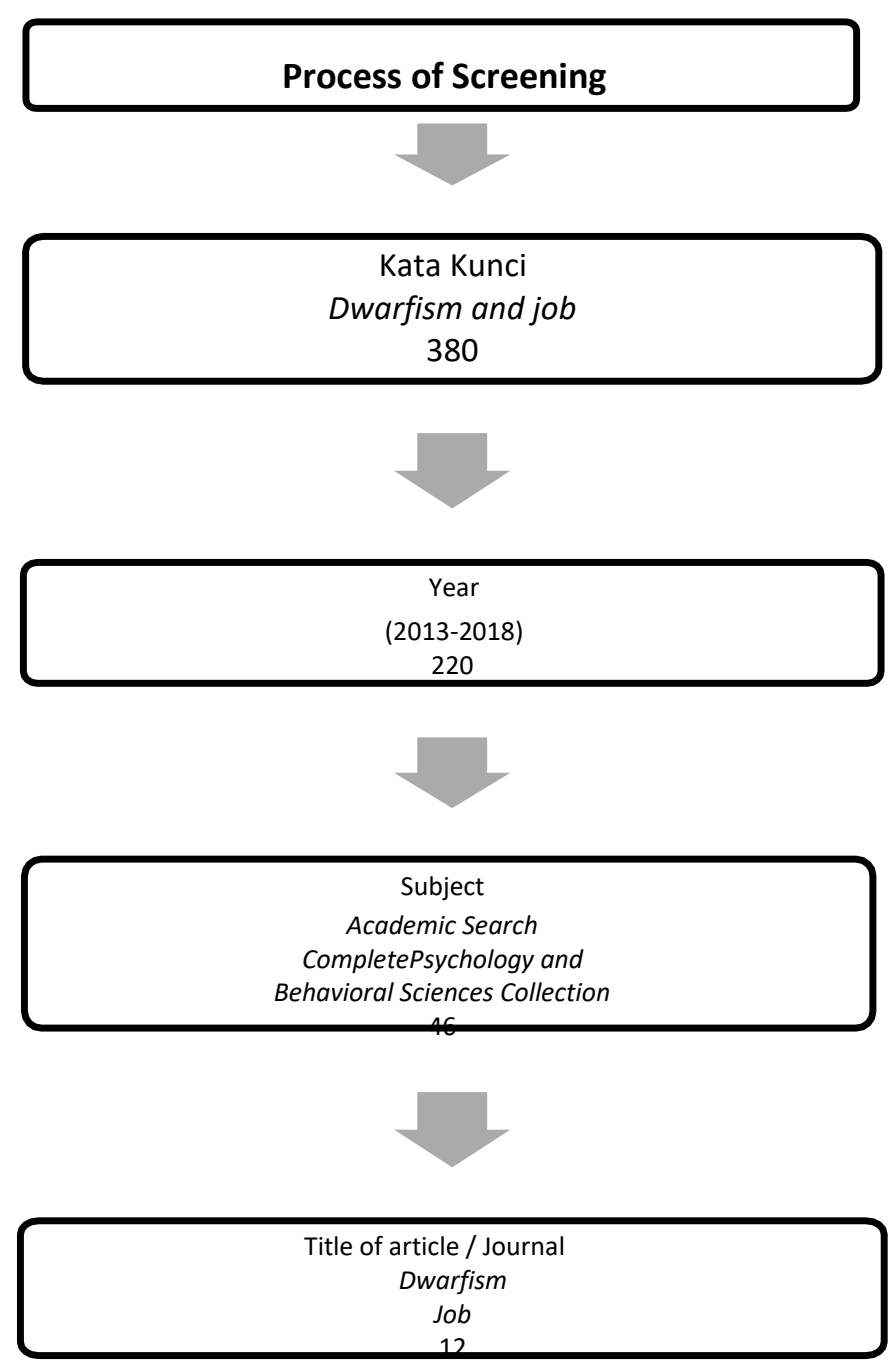

Figure 1: Process of Screening

\section{Findings}

Summary of findings of information from selected articles as in Table 2. Articles have been summarized and presented in the form of author name, year of publication, article title, country, study sample and research results related to the objectives of this assignment 
Table 2. Summary of selected literatures

\begin{tabular}{|c|c|c|c|c|}
\hline $\begin{array}{l}\text { Authors } \\
\text { names } \\
\text { years }\end{array}$ & Article Title & Country & Study Sample & Results \\
\hline $\begin{array}{l}\text { Jung-Ran Kim, } \\
\text { Hong-Joong }\end{array}$ & $\begin{array}{l}\text { Quality of life of } \\
\text { adults }\end{array}$ & $\begin{array}{l}\text { South } \\
\text { Korea }\end{array}$ & $\begin{array}{l}246 \\
\text { Workers }\end{array}$ & $\begin{array}{lr}\text { Know } & \text { the } \\
\text { perception } & \text { of }\end{array}$ \\
\hline $\begin{array}{l}\text { Cho \& Sang- } \\
\text { Gu Kim (2015) }\end{array}$ & $\begin{array}{l}\text { dwarfism-focused on } \\
\text { the perception of } \\
\text { social welfare- } \\
\text { related workers }\end{array}$ & & & $\begin{array}{l}\text { social welfare } \\
\text { workers on the } \\
\text { quality of life of } \\
\text { adult dwarfs. }\end{array}$ \\
\hline $\begin{array}{l}\text { Nasrudin } \\
\text { Baidi, Asleen } \\
\text { Ilias \& Ruziah } \\
\text { Ghazali (2018) }\end{array}$ & $\begin{array}{l}\text { The study of little } \\
\text { people in Malaysia- } \\
\text { barriers } \\
\text { challenges }\end{array}$ & Malaysia & $\begin{array}{l}\text { Dwarfs Malaysia } \\
\text { (PKOKM) } \\
45 \text { members } \\
20 \text {-male } \\
25 \text {-female }\end{array}$ & $\begin{array}{l}\text { Identify the } \\
\text { challenges faced } \\
\text { by the dwarves in } \\
\text { Malaysia through } \\
\text { experience. }\end{array}$ \\
\hline $\begin{array}{l}\text { Robert J. } \\
\text { Kruse (2002) }\end{array}$ & $\begin{array}{l}\text { Social Spaces Of Little } \\
\text { People: } \\
\text { Experiences of The } \\
\text { Jamisons }\end{array}$ & USA & $\begin{array}{l}\text { Case study- } \\
\text { couple of dwarfs } \\
\text { (family } \\
\text { Jamison) }\end{array}$ & $\begin{array}{l}\text { Identify the } \\
\text { concept of space- } \\
\text { related to human } \\
\text { body size. }\end{array}$ \\
\hline $\begin{array}{l}\text { Johnny } \\
\text { (2018) }\end{array}$ & $\begin{array}{l}\text { Were Happy With } \\
\text { Who We Are }\end{array}$ & USA & $\begin{array}{l}\text { Interview dwarf } \\
\text { couple (Lea Smith } \\
\text { \& Joe Stramondo) }\end{array}$ & $\begin{array}{l}\text { Know the } \\
\text { challenges faced } \\
\text { and how to deal } \\
\text { with them. }\end{array}$ \\
\hline $\begin{array}{l}\text { Dan Greene } \\
(2017)\end{array}$ & Serious Bussiness & USA & $\begin{array}{l}\text { Interview Dwarf } \\
\text { Athletes }\end{array}$ & $\begin{array}{l}\text { Know the } \\
\text { challenges faced } \\
\text { and how to deal } \\
\text { with them. }\end{array}$ \\
\hline $\begin{array}{l}\text { Nitasha } \\
\text { Dhiman, Alia } \\
\text { Albaghdadi, } \\
\text { Cheryl K. Zogg, }\end{array}$ & $\begin{array}{l}\text { Factors associated } \\
\text { with } \\
\text { health-related } \\
\text { quality of life }\end{array}$ & USA & $\begin{array}{l}189 \text { Dwarfs, all } 18 \\
\text { and above }\end{array}$ & $\begin{array}{l}\text { Measure the } \\
\text { quality of life of } \\
\text { the dwarves. }\end{array}$ \\
\hline Meesha & (HRQOL) in adults & & & \\
\hline $\begin{array}{l}\text { Sharma, Julie } \\
\text { E. Hoover- } \\
\text { Fong, Michael } \\
\text { C. Ain, \& Adil }\end{array}$ & $\begin{array}{l}\text { with } \\
\text { short stature skeletal } \\
\text { dysplasias }\end{array}$ & & & \\
\hline $\begin{array}{ll}\text { H. } & \text { Haider } \\
(2017) & \end{array}$ & & & & \\
\hline $\begin{array}{l}\text { Erin Pritchard } \\
(2014)\end{array}$ & $\begin{array}{l}\text { Body Size And The } \\
\text { Built Environment: } \\
\text { Creating An Inclusive }\end{array}$ & $\begin{array}{l}\text { United } \\
\text { Kingdom }\end{array}$ & Article review & $\begin{array}{l}\text { Adjust the } \\
\text { diversity of body } \\
\text { sizes with access }\end{array}$ \\
\hline & $\begin{array}{lr}\text { Built } & \text { Environment } \\
\text { Using } & \text { Universal } \\
\text { Design } & \end{array}$ & & & $\begin{array}{l}\text { to environmental } \\
\text { facilities. }\end{array}$ \\
\hline $\begin{array}{l}\text { Jeremy D. } \\
\text { Heider, Cory } \\
\text { R. Scherer, \& }\end{array}$ & $\begin{array}{l}\text { Cultural Stereotypes } \\
\text { And Personal Beliefs }\end{array}$ & USA & 400 adults & $\begin{array}{l}\text { Identify } \\
\text { stereotypes and } \\
\text { cultural beliefs of }\end{array}$ \\
\hline
\end{tabular}




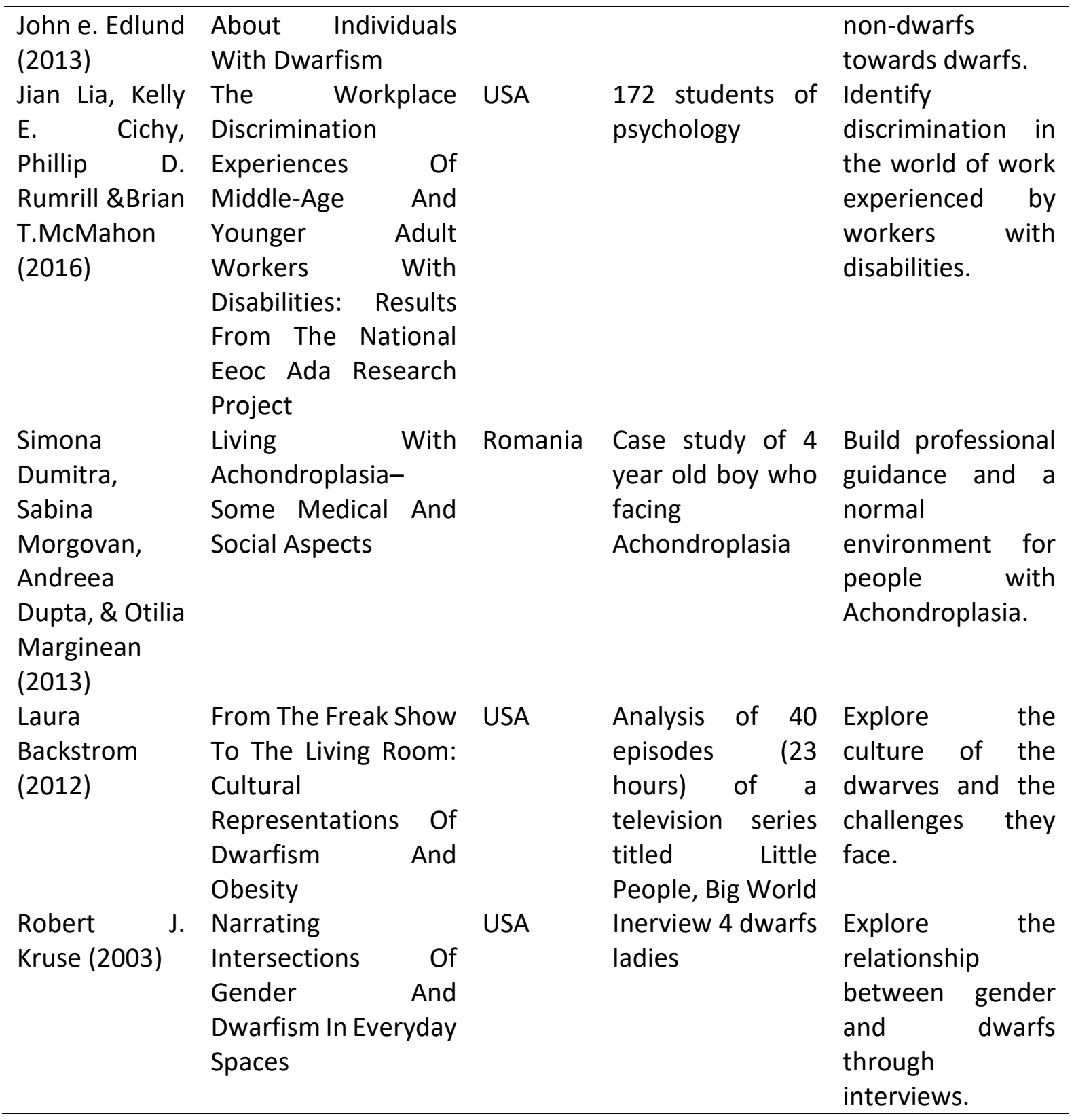

\section{Discussion}

\section{Dwarfism Statistics in Malaysia}

The latest number of dwarves in Malaysia is unknown. This is due to the statistical databased for this specific group was not available (Baidi et al., 2018). The individual who identified as dwarf in Malaysia is not necessarily to register as disabilities (Lee et al., 2011). A dwarf association in Malaysia was established in 1984, the National Association of Dwarves of Malaysia (PKOKM). Members of the association are individuals with height less than $142 \mathrm{~cm}$ for men and $138 \mathrm{~cm}$ for women. To be a member of the dwarf association, they need to be certified by government medical officer as classification as category of dwarf. The total number of the membership is 134 comprising of different location, social background, and job background (Baidi et al., 2018). PKOPM is aim to help the group of dwarfs look in their area of interest, extend different type of assistant, develop self-empowerment within the dwarf, create an exemplary successful society of dwarf, create awareness for the public about dwarf and cooperate with government and NGOs for build up the well-being dwarf 
community in Malaysia (Baidi et al., 2018). The resources for these categories are very limited in Malaysia.

\section{Challenges Faced By Dwellers}

The challenges of the various disabilities and achievements in the field of work are most worrying. This is because working alone can help these people out of poverty and be selfreliant (Ang et al., 2013). Therefore, the Government of Malaysia (through the Disability Act 2008) promulgated a policy that recommended that the public and private sectors allocate $1 \%$ of employment opportunities in the organization to the disabled (Lee et al., 2011; Falina, et al., 2015). However, the government's efforts have been fruitless as unemployment rates among the disabled remain high in Malaysia. Over 95\% of people with disabilities are still unemployed even though they say they are capable and able to work like other normal people but are still not given the opportunity by their employers. This is because even though the government has passed the act, no enforcement has been made against employers or organizations that do not comply with the policy and discriminate against the disabled which has made the act unsuccessful (Ang, 2014). Moreover, the legal aspects of the enforcement of this act are still lacking, unless the values, beliefs, and awareness of this group's attention have changed. People with disabilities actually expect the Disability Act 2008 to be fully implemented to give these people the right to get a job.

Social and Environmental

Dwarfs often suffer from stress during their developmental stages unlike others, especially from the physical perception. As a result, many in this group avoided social interaction. Negative self-esteem or lack of self-esteem aggravated relationships with society and left them isolated by society. They also seem to alienate themselves from society as they often experience discrimination when trying to get along with the community. These experiences indirectly influenced the psychological and emotional aspects of their life (Kim et al., 2015). People with dwarfism also get stereotypes that they are less capable than normal people. Also, these groups are often ridiculed and humiliated. This also causes the dwarf to drop out of school or quit their jobs because they are being bullied and constantly mocked (Baidi et al., 2018).

Public transport is also a major challenge for dwarves especially those in wheelchairs (Kim et al., 2015). During peak or working hours, dwarves will be crowded by peoples and this exposes them to the more dangerous situation due to their medical issues. Not only that, but the structure of public facilities also makes it difficult for the dwarves to use the facilities comfortably. For example, the staircase heights (especially buildings without elevators and ramps), elevations of ATMs, service counters at various public and private organizations (e.g. Post Office and Bank), public toilets, and more. Therefore, the public's awareness of the situation of the dwarfs is still low and ignored. Whereas they struggle in most situations to find the same comfort as other normal people (Kruse, 2002).

Unfortunately, some studies have shown that these dwarves also underestimated by their parents, especially if the child is sent to a special education school for the disabled (Watson, et al., 1999; Shah, et al., 2004; in Lee et al., 2011). Besides, some parents are too protective and to distance their children from the real world, for the fear of harming their children. This act causes them to become self-reliant, low self-esteem, and alienate themselves from society. As they grow older, these factors also prevent them from getting a job (Baidi et al., 2018).

Medicine 
Dwarfism mostly struggles with long-term medical issues. Children born with dwarfism or achondroplasia often experience trauma to their appearance. As a result, there are cases where they are offered medical and surgical treatment to modify the current situation to make it easier to adapt to society. One of the most common treatments available is hormone therapy. This therapy is used in the early stages of childhood development where the growth process is at a rapid pace that allows the child to reach the minimum and normal height. Also, there is a surgical solution that extends the legs and arms up to a maximum height of $30 \mathrm{~cm}$. The main purpose of this treatment is to make it look like normal human height but it is more to enable these groups to be independent and adaptable to the society and surroundings.

Besides, dwarfs also suffer from cervicomedullary compression. If left untreated, the pressure on the base of the brain can result in sudden death or paralysis especially for children under 4 years old. This is due to growth conditions stagnation does not coincide with the growth of the brain organs. Because there is no space, the base of the brain that connects to the spine is narrowed and causes nerve and fluid disturbance (Ozcetin et al., 2012).

Children with dwarfism also suffer from sleep disorders (apnea, hypopnea). This problem is caused by narrow nasal and respiratory cavities resulting in a lack of oxygen to the brain and body functions (Julliand, et al., 2012). Sometimes they can stop breathing or unconscious during sleep which can lead to death. Therefore, as a precautionary measure, systematic sleep tests should be conducted periodically as a yearly routine for continuous assessment. Occasionally surgery should be performed if routine evaluation finds it to be dangerous (Julliand, et al., 2012).

Careers Life

The challenge of the dwarfs in the world of work is the greatest. This is because work is the source or essence of life for survival such as food, clothing, and shelter. Although the Malaysian government has introduced the Disability Act 2008 which requires the public and private sectors to employ these groups, it still does not help as there is no law enforcement force (Ang, 2014). The result is that many employers do not want to get these people working on their physical factors despite their high academic qualifications. Many jobs are also offered only for the lower-class categories. This is because employers are not convinced with the capabilities of these dwarfs. Although their intellect is as normal as anyone else, only physical appearance to be different (Safilios- Rothschild, 1970; in Ang, 2014).

Employers or organizations that are less aware will feel that employees from these small groups are increasing their management costs due to the provision of specialized facilities and expensive medical care. Employers are also concerned that the facility will cause other workers to feel unfair and jealous of the workers because they seem to be privileged and cause the workers to become marginalized and quit (Baidi et al., 2018). The degree to which employers are willing to accept workers with disabilities into the organization also influences the workforce's success in securing employment. Careful and open organizations are more likely to accept this group of employees (Ang, 2014).

The greatest challenge for a dwarf in the workplace is not the work task, it about the relationship and human behavior (Baidi et al., 2018; Heider et al., 2013). Workplace challenges commonly encountered by these dwarfism groups include discrimination, exploitation, and bullying, payroll, relationship with supervisor, organizational support, and workplace adjustment (Ang, 2014). Lack of social skills has to make dwarfs have negative selfconcept and lack of self-confidence. It facilitated these groups of individuals to become victims of discrimination, exploitation, and bullying in the workplace which eventually led them to quit their jobs. Not only that, they have also become accustomed to the experience 
of discrimination as they have often experienced in education, training, and employment since childhood (Lee, Abdullah \& Mey, 2011). If these perceptions persist, it will affect their career aspirations and limit the job opportunities they should have.

The condition of office buildings built according to normal height standards also makes it difficult for these dwarves to work. For example, lift button, switch position, table height, toilet height, door and access card height, and counter height. Not only that, the distance from one department to another makes it difficult for them to move from one department to another. There are also office buildings that are not electric wheelchairs. This makes it difficult for some of the dwarves to find jobs. In addition, public transport is also built to the standard and dangerous standard. Private vehicles, where require a high cost of repairs before they can be used. Sometimes these vehicles need to be imported from abroad (Pritchard, 2014). Therefore, the real obstacles of the dwarf in the pursuit of employment are the views of the community and coworkers, the flexible organizational culture, the challenges of the workplace, the parents who are too protective to look down on their abilities, low selfesteem, and lack of confidence. Social skills have also been identified as a hindrance to them getting or staying in a job for a long time. To the extent that these dwarves succeed in securing employment, it is considered their luck rather than their ability (Lee, Abdullah \& Mey, 2011).

\section{How to Deal with Challenges}

Family relationships play an important role in influencing the level of individual adaptation and suicide of a person. According to Kim, Cho, \& Kim (2015), families are major support and force for dwarfism patients, especially adults. These include expectations of family roles such as emotional support, empathy, and family encouragement, external family-based support, in addition, to support and counseling information to dwarfs' family members. Besides, positive health factors and interpersonal relationships can also improve the quality of life in terms of age and career. This shows that human relationships greatly influence the psychological aspects of dwarfism.

People with dwarfism have the power to not easily overcome high social (physical and psychological) barriers. As a result of being used to the same challenges over and over again, they succeed in living better lives than other normal people. They are more resilient in adapting to society and the environment. This is evident from the breakthroughs that have been featured in a television series on TLC titled Little Couple, a dwarf who's wife is a medical doctor while her husband is a businessman. Through the television program, they were seen as daring and clueless in the surrounding community as if there were no problems in the context of discrimination and exploitation. The cynical response of the public was also responded to with a smile and a smile (Baidi et al., 2018).

The role of the mass media in introducing the world of dwarfs to society is seen to have increased the general awareness of these groups. The influence of the media in the television series on showing the positive side of this group has affected the community. The reception and service of the community to this group were more positive than in the past. Parents with dwarfs are no longer shy or worried about their children's safety, and more people are sending their dwarves to regular schools because these dwarfs are just as smart as other normal people. Therefore, people with dwarfism should not be considered disabled because they are mentally normal (Guse \& Harvey, 2010). Additionally, in developed countries such as America, the mindset of dwarfism has begun to change as they have professional careers and high standards of living. Now their physical condition became a symbol of identity as previously seen as disabled. This may be because these groups are now more vocal in 
communicating information across various communication platforms about their self-efficacy and thus create confidence among the public that they are just like any other normal person (Heider, Scherer, \& Edlund, 2013).

A dwarf association in Malaysia was established in 1984, the National Dwarf Society of Malaysia (PKOKM). The organization is responsible for (1) assisting the target group of people with dwarfism; (2) provide training in areas of interest and identify the dwarf community in Malaysia; (3) cultivate values and instill a spirit of mutual understanding and create a dynamic, independent, economically productive dwarf community, socially and nationally aware of the benefits. (4) undertake various activities and collaborations with various government agencies, private agencies, and other NGOs to produce successful dwarf communities as examples to other dwarf communities; and (5) constantly striving to bring awareness to the dwarf community and to improve their standard of living through charity and charity work. Overall, this organization has helped to lift the status of the dwarves forward as a group of individuals with the best ability.

\section{Implications}

Currently, only 1500 individuals with various categories of disability are employed in the Malaysian government sector (Falina, et al., 2015; Baidi et al., 2018). This number is smaller than the 1.4 million targets (as suggested by the Disability Act 2008 which requires that $1 \%$ of job opportunities be given to the disabled by the total number of employees in an organization). An implementation guide related to hiring needs to be developed to support the implementation of the policy. Studies show that employers will only comply with policies if they have clear information about a policy (Jackson, et al., 2000; in Ang, 2014). Therefore, educating employers and developing strategies to address these issues is essential to ensuring the effectiveness of a policy in Malaysia. Enacting legislation on employment quotas, emphasizing the dissemination of relevant information through popular media (television, websites) to raise public awareness (Lee, Abdullah \& Mey, 2011), and establishing a culture of tolerance, openness, and understanding are key pillars required by workers with disabilities in the workplace. Hiring workers with disabilities should be considered based on the individual's skills, abilities, and qualifications, not due to sympathy or legal pressure to quota alone (Ang, 2014).

A stable career is also an important factor in helping those with dwarfism develop selfreliance, self-esteem, self-confidence, and self-esteem. According to Lee et al. (2011), Malaysia has provided vocational training to people with disabilities. Special workshops for these groups were created to provide them with space and opportunity to develop themselves in the world of work and to enhance their social skills. Positive social interactions among the dwarves will be the catalyst and encouragement for them to boldly improve their abilities and to engage in community activities. The results of this study also show that support for peers in the same category through the medium of interaction and communication is very helpful in the process of adjustment and psychological adaptation for adults or older, while family support is important for the process of adjustment and psychological adaptation to younger people. (Wilson et al., 2006). Today, the interaction between them is almost always over the internet (such as websites, Whatsapp applications, etc.) to ensure that everyone has the most common benefit whether the dwarves or the general public (Baidi et al., 2018).

The results of previous studies also indicate that the main challenge of the dwarves is that the negative attitude and attitude towards the group is due to the lack of public information 
about the dwarves. So much so that the dwarves are seen as defective, incapable, and weak. Although these dwarves are just as capable as other normal humans, they are sometimes more successful in their field. This is because they are physically different from the normal human size but the intelligence and intelligence of the dwarves are just as normal. When various mass media such as reality television shows show the real side of the dwarf made public (such as a TLC channel called Little Couple), Little People, Big World. dwarfs and a combination of normal and dwarf children), Our Little Life (Dwarf parents with normal child sizes), and The Little Chocolatiers (Dwarf husband and wife running a chocolate business), show the public about their ability in life and change the negative stigma of society over the years. These television shows also show that dwarf is an identity that society can boast of having its unique advantages over other normal people. Although there are still others who view them as strange, at least people are treated with respect and dignity (for example, when they talk to these dwarves and treat them in the same way as others). They are also not seen for sympathy, bizarre, and humorous factors but are part of a society that is no different (McKay, 2010).

\section{Conclusion}

The purpose of this assignment is to discuss and present the findings of previous studies and policies in addition to knowledge sharing to be shared at all levels of society, especially those with dwarfism. The sharing of knowledge is expected to increase public awareness of the dwarfs as well as inspire the dwarves to continue to improve. Throughout this work, the author uses the word 'special group' rather than 'disabled' although the act in Malaysia uses the word 'disabled' since these dwarves are capable and able to compete with other normal people. This shows that they are not 'disabled' but with the gift of God of special ability. Besides, the finding also indicate that the challenges of dwarfs is greater than others in the working field. Based on the previous result showed the challenges of dwarfs in work place is not about their task, it is the relationship issues. Dwarfs facing discrimination in their work place. The discrimination causes them lose confident and normally will develop negative selfconcept. Furthermore, the lack of social skill cause dwarfs facing the issue of communication. Misunderstanding and bully case easily happen when they do not how to communicate with others. The relationship issues make the dwarfs have limited job opportunities.

The establishment of the National Dwarf National Organization of Malaysia (PKOKM) has brought about significant changes to the development of the welfare of the dwarf in Malaysia. However, the total membership of this dwarf of only 150 people where it is still a very small amount. This shows that many dwarves are out there alone and need help. Therefore, previous studies in Malaysia were not able to fully describe these dwarfs due to the small sample size. As such, PKOKM needs to diversify partnerships between the private and government sectors to develop programs for the community. In addition to playing the role of disseminating public information to the public to turn the stigma of society into a positive one (ie looking at them in terms of ability and achievement rather than sympathy and compassion), this organization needs to carry out a membership inclusion campaign for all minorities in Malaysia. It is also suggested that memberships also offered to family members of the dwarfs which will certainly have the long-term benefits of expanding their communication network with positive information about the dwarves. This is because the dwarf family members also need support from each other in the form of psychology and guidance in helping the dwarf. Indirectly, more realistic membership data will be available and will surely benefit the private and government education sectors in conducting 
development studies to be more significant and comprehensive about the disability groups in the future. These studies can also contribute to the exploration of new information and knowledge on dwarfism-related disorders, particularly in Malaysia.

Finally, it is also advisable to appoint an official representative of a minority of dwarfism to represent the minority of dwarfism in the policymaking processor to a variety of other professional areas as it is appropriate to assess the context and needs of the dwarfism. The presence of representatives of these dwarfs will increase one hundred and social recognition of the existence of dwarfs in Malaysia. Besides, the relevant policymakers or statutory bodies should recommend in-depth studies of these dwarfism groups as an equally important agenda by providing grants that encourage studies of dwarfism development programs. This is one of the biggest steps that can be made in the effort to look after the welfare of those with dwarfism other than just establishing PKOKM.

\section{Acknowledgements}

This research is funded by Geran Putra IPM/2018. Thank you to research members Graduate student Ms. Nur Syuhada Abdul Rasid, Dr.Yusni Mohamad Yusop, Dr. Wan Norhayati Wan Othman and Graduate Research Assistant Mr. Lee Wei Rong

\section{Reference}

Ang, M. C. (2014). Do Persons with Disabilities Act (2008) and Organizational Culture Influence Managerial Intention to Hire Persons with Disabilities? The Malaysian Perspective. Jurnal Pengurusan, Vol. 41, 81-89

Ang, M. C., Ramayah, T., \& Vun, T. K. (2013). Hiring Disabled People in Malaysia: An Application of the Theory of Planned Behavior. The Journal of International Social Research, Vol. 6, No. 27, 50-64

Backstrom, L. (2012). From The Freak Show To The Living Room: Cultural Representations of Dwarfism and Obesity. Sociological Forum, Vol. 27, No. 3.

Baidi, N., Ilias, A., \& Ghazali, R. (2018). The Study of Little People In Malaysia - Barriers and Challenges. International Journal for Studies on Children, Women, Elderly And Disabled, Vol. 3.

Dan, G. (2017). Serious Bussiness. Retrieved from:

http://ezproxy.upm.edu.my:2204/ehost/pdfviewer/pdfviewer?vid=18\&sid=2cd6ec02-9e814252- a93b-76ec2a3bec90\%40pdc-v-sessmgr06

Di George, A., \& Paschkis, K. E. (1957). Dwarfism. Pediatric Clinics of Noth America, 4(4), $925-$ 948. https://doi.org/10.1016/S0031-3955(16)30584-3

Guse, T., \& Harvey, C. (2010). Growing Up with A Sibling with Dwarfism: Perception of Adults Non-Dwarf Siblings. Disability \& Society, 25(3), 387-401

Falina, H. R., Safura, A. S., Norazia, A. W., \& Afnee, N. Z. (2015). Kesedaran Golongan Majikan Terhadap Orang Kurang Upaya (OKU) di Malaysia: Melalui Perspektif Media (Awareness of Employers towards People with Disabilities [PWD] in Malaysia: From Media Perspective). Proceeding of the 2nd International Conference on Management and Muamalah 2015 (2nd ICoMM), 192-199, e-ISBN: 978-967-0850-25-2

Heider, J. D., Scherer, C. R., \& Edlund, J. E. (2013). Cultural Stereotypes and Personal Beliefs About Individuals with Dwarfism. The Journal Of Social Psychology, 2013, 153(1), 80-97

Johnny, D. (2018).Were Happy With Who We Are. Retrieved from : http://ezproxy.upm.edu.my:2204/ehost/pdfviewer/pdfviewer?vid=17\&sid=2cd6ec029e81-4252- a93b-76ec2a3bec90\%40pdc-v-sessmgr06 
Julliand, S., Boule, M., Baujat, G., Ramirez, A., Couloigner, V., Beydon, N., . . Fauroux, B. (2012). Lung function, diagnosis, and treatment of sleep-disordered breathing in children with achondroplasia. Am J Med Genet A, 158A(8), 1987-1993. https://doi.org/10.1002/ajmg.a.35441

Kim, J. R., Cho, H. J. , \& Kim, S. G. (2015). Quality of Life of Adults with Dwarfism - Focused on the Perception of Social Welfare-related Workers. Indian Journal of Science and Technology, Vol 8(18), https://doi.org/10.17485/ijst/2015/v8i18/7715.

Kruse, R. J. (2002). Social Spaces of Little People: The Experiences of The Jamisons. Social \& Cultural Geography, Vol. 3, No. 2.

Kruse, R. J. (2003). Narrating Intersections of Gender and Dwarfism In Everyday Spaces. Canadian Association of Geographers 47, no 4 (2003) 494-508

Lee, M. N., Abdullah, Y., \& Mey, S. C. (2011). Employment of People with Disabilities in Malaysia: Drivers and Inhibitors. International Journal of Special Education, Vol. 26, No. $1,112-124$

Lia, J., Cichyb, K. E., Rumrillb, P. D., \& McMahonc, B. T. (2016). The Workplace Discrimination Experiences of Middle-Age and Younger Adult Workers with Disabilities: Results From The National EEOC ADA Research Project. Journal of Vocational Rehabilitation 45 (2016) 365-376.

McKay, \& Hollie. (2010). "Is Learning Channel's 'Little People' Franchise 21st Century Exploitation of Dwarfism?" Fox News. Retrieved from : http://www.foxnews.com/entertainment/2010/03/25/learning-channels-littlepeople-franchise-st- century-exploitation-dwarfism/

Ozcetin, M., Arslan, M. T., \& Karapinar, B. (2012). An Achondroplasic Case With Foramen Magnum Stenosis, Hydrocephaly, Cortical Atrophy, Respiratory Failure and Sympathetic Dysfunction. Iran J Pediatr 2012 Mar;22(1):121-4.

Persons with Disabilities Act. (2008). Laws of Malaysia (Act 685), Malaysia: Percetakan Nasional Malaysia Berhad

Pertubuhan Kebangsaan Orang Kerdil Malaysia. (PKOKM), (2017). Retrieved from: http://orangkerdilmalaysia.blogspot.my/

Pritchard, E. (2014). Body Size and the Built Environment: Creating an Inclusive Built Environment using Universal Design. Geography Compass, 63-73, 10.1111/gec3.12108. Newcatle: John Wiley \& Sons Ltd

Wilson, S., Washington, L. A., Engel, J. M., \& Ciol, M. A. (2006). Perceived Social Support, Psychological Adjustment, and Functional Ability in Youths with Physical Disabilities. Rehabilitation Psychology, 51(4), 322-330. https://doi.org/10.1037/00905550.51.4.322 